\title{
Influence of Temperature on Anaerobic Co-digestion of Dairy Manure and Edible Mushroom Cultivation Waste
}

\author{
Chunlin $\mathrm{Li}^{1, \mathrm{a}}$, Huifen Liu ${ }^{1, \mathrm{~b}}$, Jianchao Hao ${ }^{1, \mathrm{c}}$, Weiyu Zhang ${ }^{2,3, \mathrm{~d}}$, Litong Ban ${ }^{1, \mathrm{e}}$ \\ and Lijun Shi ${ }^{1,2, f}$ \\ ${ }^{1}$ College of Agronomy \& Resources and Environment, Tianjin Agricultural University, Tianjin \\ 300384, China \\ ${ }^{2}$ China-Japan Collaborative Research Center for the Rural Environment and Resource, Tianjin \\ 300384, China \\ ${ }^{3}$ College of Engineering and Technology, Tianjin Agricultural University, Tianjin 300384, China \\ a403928591@qq.com, bliuhuifen@eyou.com, 'qqhjc1980@163.com, d525156985@qq.com, \\ ebanlitong@126.com, shilj898@126.com (corresponding author)
}

Keywords: Anaerobic co-digestion, biogas, dairy manure, edible mushroom cultivation waste, temperature, second feed.

Abstract. Anaerobic co-digestion of dairy manure and edible mushroom cultivation waste was conducted to produce biogas using batch reactor. Influence of temperature on anaerobic digestion was studied, and recovery ability of bacterial activity after second feed was also investigated. Three temperature conditions of room temperature condition $\left(16.5^{\circ} \mathrm{C}-25^{\circ} \mathrm{C}\right)$, mesophilic condition $\left(36^{\circ} \mathrm{C}\right)$ and thermophilic condition $\left(55^{\circ} \mathrm{C}\right)$ were chosen, and experimental result indicated that room temperature was unfit for anaerobic digestion. Anaerobic digestion under mesophilic condition and thermophilic condition proceeded well, and the latter had earlier and higher daily biogas production peak. Second feed period achieved higher biogas yields of $199 \mathrm{~mL} \cdot \mathrm{g}^{-1} \mathrm{VS}$ and $222 \mathrm{~mL} \cdot \mathrm{g}^{-1} \mathrm{VS}$ under mesophilic condition and thermophilic condition respectively without lag phase. Seven to ten days of lag phase existed and biogas yields were $190 \mathrm{~mL} \cdot \mathrm{g}^{-1} \mathrm{VS}$ and $213 \mathrm{~mL} \cdot \mathrm{g}^{-1} \mathrm{VS}$ respectively under same conditions during first feed period. These results could provide beneficial information for scaled project.

\section{Introduction}

Anaerobic biogas digestion is a biochemical process, in which anaerobic microorganisms degrade organic substance into methane and carbon dioxide [1]. Since biogas is a kind of renewable energy sources and can be utilized as alternatives of fossil fuels to reduce greenhouse gases emission, anaerobic digestion is of significant environmental and ecological benefits [2].

China is a large agricultural country and produces an enormous amount of animal products and edible mushroom products each year, meanwhile large quantity of animal manure and edible mushroom cultivation waste are produced [3]. With transformation of rural life style and agricultural production mode in recent years, animal manure and edible mushroom cultivation waste could not be used efficiently and large quantities of these matters were abandoned at random [4]. In fact animal manure and edible mushroom cultivation waste contain abundance of organic substance and nutrients, so using these substances as feedstock for anaerobic digestion to produce biogas not only can decrease environmental pollution but also can reuse biomass resources [5].

Temperature is a main influence factor on anaerobic digestion and microorganism can grows in the suitable temperature range between $8^{\circ} \mathrm{C}$ and $65^{\circ} \mathrm{C}$. According to operation temperature, anaerobic digestion can be classified as low temperature digestion, mesophilic digestion and thermophilic digestion. In general microorganism under thermophilic condition has higher biogas production than under mesophilic condition because of higher biological activity [6]. 
In this work, anaerobic co-digestion of dairy manure and edible mushroom cultivation waste was conducted to produce biogas using batch reactor. Influence of temperature on anaerobic digestion was studied, and recovery ability of bacterial activity after second feed was also investigated.

\section{Material and Method}

Substrates. Dairy manure was collected from a scaled farm in Xiqing District of Tianjin City and was dried and shredded to particles less than $5 \mathrm{~mm}$. Edible mushroom cultivation waste was obtained from a scaled mushroom cultivation farm in same district as above and dried in an air. Inoculation sludge was taken from a thickener at Tianjin Xianyang Road Wastewater Treatment Plant and cultivated for a week in mesophilic condition $\left(36^{\circ} \mathrm{C}\right)$ with dairy manure and edible mushroom cultivation waste as feed. Table 1 shows the characteristics of raw materials.

Table 1 Characteristics of manure manure, edible mushroom cultivation waste and inoculation sludge

\begin{tabular}{cccccc}
\hline & TS [\%] & VS [\%] & TC $[\mathrm{g} / \mathrm{kg}]$ & $\mathrm{TN}[\mathrm{g} / \mathrm{kg}]$ & $\mathrm{C} / \mathrm{N}$ ratio \\
\hline Dairy manure & $98.5 \%$ & $43.1 \%$ & 267.9 & 15.0 & 17.9 \\
$\begin{array}{l}\text { Edible mushroom } \\
\text { cultivation waste }\end{array}$ & $97.9 \%$ & $83.2 \%$ & 599.7 & 16.8 & 35.7 \\
Inoculation sludge & 2.88 & 69.4 & 352 & 30.6 & 1.15 \\
\hline
\end{tabular}

Digestion System. The schematic diagram is shown in Fig. 1. The whole system consists of digestion bottle, gas collection bottle, water collection bottle, gas pipe and water pipe. The digestion bottle is constructed from glass with total volume of $0.5 \mathrm{~L}$ and is equipped with a rubber plug to keep anaerobic environment. A hole is drilled through the plug to fix plastic pipe for biogas collection. Leachate is sampled from a sampling port on the side of the digestion bottle for characteristic analysis. Dairy manure, edible mushroom cultivation waste and inoculation sludge were combined and placed into the digestion bottles, and tap water was also added to adjust TS content. Biogas produced from digestion bottle flew through gas pipe to gas collection bottle, which was filled with saturated salt water. Furthermore saturated salt water was pressed through water pipe to water collection bottle, and then the volume of water was measured to calculate the biogas amount.

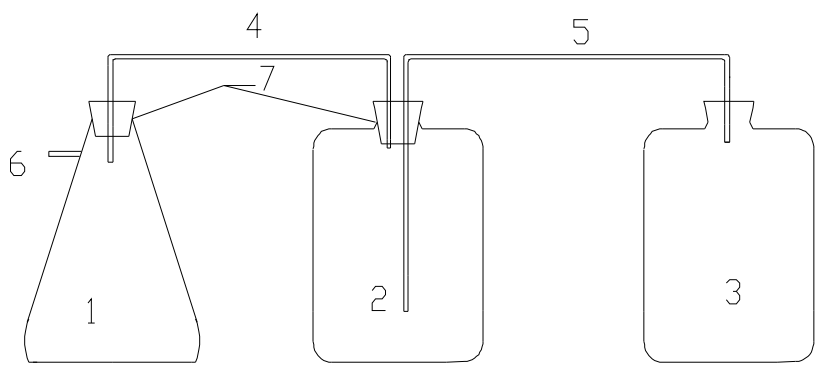

1 Anaerobic digestion bottle 2 Gas collection bottle 3 Water collection bottle 4 Gas pipe 5 Water pipe 6 Leachate sampling 7 Sealed plug

Fig. 1 Schematic diagram of experimental equipment

Experimental Methods. The whole experiment was divided into two periods, which were first feed period and second feed period respectively. A second feed was performed in order to examine the recovery ability of bacterial activity after substrates exhaustion. In each period, mixtures of dairy manure and edible mushroom cultivation waste with a ratio of 2:1 (mass ratio) were added into three digestion bottles to form a suitable $\mathrm{C} / \mathrm{N}$ ratio, then three bottles were placed in the laboratory, a $36^{\circ} \mathrm{C}$ water bath container and a $55^{\circ} \mathrm{C}$ water bath container respectively to form room temperature unit (RTU), mesophilic unit (MU) and thermophilic unit (TU). Inoculation sludge and tap water were also placed into each bottle. 
During first feed period dairy manure and edible mushroom cultivation waste were $33.5 \mathrm{~g}$ and 16.5 $\mathrm{g}$ respectively, and tap water and inoculation sludge were $300 \mathrm{~mL}$ and $150 \mathrm{~g}$ respectively to form $10 \%$ TS content and $10 \%$ inoculation percentage, which was shown in table 2 . During second feed period $16.5 \mathrm{~g}$ dairy manure and $8.5 \mathrm{~g}$ edible mushroom cultivation waste were placed into same unit as first period, and $225 \mathrm{~mL}$ tap water was also added without inoculation sludge addition (Table 2).

Table 2 Composition of mixed raw materials

\begin{tabular}{cccccc}
\hline Period & Units & Dairy manure [g] & $\begin{array}{c}\text { Edible mushroom } \\
\text { cultivation waste }[\mathrm{g}]\end{array}$ & $\begin{array}{c}\text { Inoculum sludge } \\
{[\mathrm{g}]}\end{array}$ & $\begin{array}{c}\text { Tap wate } \\
\mathrm{r}[\mathrm{mL}]\end{array}$ \\
\hline First & RTU & 33.5 & 16.5 & 150 & 300 \\
feed & MU & 33.5 & 16.5 & 150 & 300 \\
period & TU & 33.5 & 16.5 & 150 & 300 \\
\hline Second & RTU & 16.5 & 8.5 & 0 & 225 \\
feed & MU & 16.5 & 8.5 & 0 & 225 \\
period & TU & 16.5 & 8.5 & 0 & 225 \\
\hline
\end{tabular}

Analytical Methods. The analysis items were biogas production, water bath temperature, total solid (TS), volatile solid (VS), total carbon (TC) and total nitrogen (TN) of raw materials, $\mathrm{pH}, \mathrm{NH}_{4}{ }^{+}-\mathrm{N}$, volatile fatty acid (VFA) and alkalinity of leachate samples. Biogas production, water bath temperature were monitored every day. TS, VS, TC and TN were measured prior to and at the end of digestion. Leachate samples were collected periodically for analysis of $\mathrm{pH}, \mathrm{NH}_{4}{ }^{+}-\mathrm{N}$, volatile fatty acid (VFA) and alkalinity. COD was measured by the closed reflux method. $\mathrm{NH}_{4}{ }^{+}-\mathrm{N}$ was measured using photospectrometry. $\mathrm{pH}$ was determined using a $\mathrm{pH}$ meter. Other items were analyzed as mentioned elsewhere [7-8].

\section{Results and Discussion}

First Feed Period. The average and cumulative biogas production during first period is depicted in Fig. 2. It could be seen that RTU had few biogas production, which indicated room temperature is unfit for anaerobic digestion. Different from RTU, MU and TU showed high biogas production performance. During first feed period both MU and TU existed lag phases of seven to ten days, then biogas production increased gradually. Compared to MU, TU showed earlier and higher daily biogas production peak with a maximum biogas production of $737 \mathrm{~mL}$ on 15th day and average biogas production about $172 \mathrm{~mL}$ during whole period of 35 days. Whereas daily biogas production peak of MU was $498 \mathrm{~mL}$ on 21 st day, and average biogas production was about $153 \mathrm{~mL}$ during same period of 35 days.
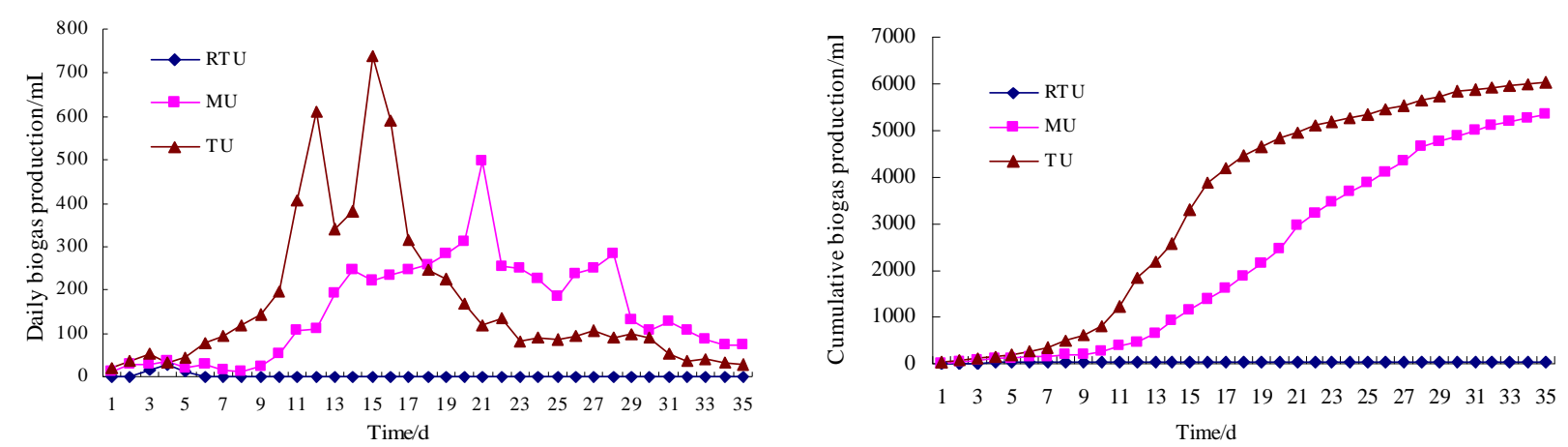

Fig.2 Variations of daily and cumulative biogas yield during first feed period 
During first feed period, the cumulative biogas production of MU and TU were $5348 \mathrm{~mL}$ and 6028 $\mathrm{mL}$ respectively. Since added volatile solids (VS) of MU and TU was both $28.2 \mathrm{~g}$, so biogas yields of MU and TU were $190 \mathrm{~mL} \cdot \mathrm{g}^{-1} \mathrm{VS}$ and $213 \mathrm{~mL} \cdot \mathrm{g}^{-1} \mathrm{VS}$ respectively. Compared to MU and TU, RTU showed few biogas production of $55 \mathrm{~mL}$ during whole digestion period, which indicated room temperature is unfit for anaerobic digestion.

Characteristics of leachate during first period were shown in Table 3. It could be seen that VFA concentration in the leachate of RTU was $1.12 \mathrm{mmoL} / \mathrm{L}$ with a low $\mathrm{pH}$ of 5.80, whereas that of MU and TU were $0.95 \mathrm{mmoL} / \mathrm{L}$ and $0.74 \mathrm{mmoL} / \mathrm{L}(6.01$ and $6.01 \mathrm{of} \mathrm{pH})$ respectively at same time. It was reported that high VFA could inhibit the activity of microorganism [9], so digestion of RTU might have been inhibited. From Table 3 it also could be found that MU and TU had higher alkalinity $(0.90$ $\mathrm{mmoL} / \mathrm{L}$ and $0.96 \mathrm{mmoL} / \mathrm{L}$ respectively) and $\mathrm{NH}_{4}{ }^{+}-\mathrm{N}$ concentrations $(215 \mathrm{mg} / \mathrm{L}$ and $218 \mathrm{mg} / \mathrm{L}$ respectively), which could have buffering effect to VFA to avoid low $\mathrm{pH}$.

Table 3 Characteristics of leachate during first period

\begin{tabular}{cccc}
\hline & RTU & MU & TU \\
\hline $\mathrm{pH}$ & 5.80 & 6.01 & 6.15 \\
Alkalinity [mmol/L] & 0.88 & 0.90 & 0.96 \\
$\mathrm{NH}_{4}{ }^{-}-\mathrm{N}[\mathrm{mg} / \mathrm{L}]$ & 121 & 215 & 218 \\
VFA $[\mathrm{mmol} / \mathrm{L}]$ & 1.12 & 0.95 & 0.74 \\
\hline
\end{tabular}

Second Feed Period. Due to substrates exhaustion and low biogas production at the end of first feed period (after 30 days of incubation, seen from Fig. 2.), second feed was added to investigate the recovery ability of bacterial activity with a half amount of substrate as the initial one (Table 2).

The average and cumulative biogas production is depicted in Fig. 3. Same as first period, RTU showed weak biogas-producing performance during whole period with a little biogas production of several days. The daily biogas production of MU and TU increased gradually without initial lag phase, and attained biogas production peak of $395 \mathrm{~mL}$ on 7 th day and $502 \mathrm{~mL}$ on 4th day respectively. Compared to MU, TU also had earlier higher daily biogas production peak with average biogas production about $166 \mathrm{~mL}$ during whole period of 19 days, whereas average biogas production of MU was $149 \mathrm{~mL}$ during same period.

The daily biogas production of MU and TU decreased gradually, and was less than $100 \mathrm{~mL}$ after 13 days. The cumulative biogas production of MU and TU attained $2827 \mathrm{~mL}$ and $3156 \mathrm{~mL}$ respectively with average biogas production of $149 \mathrm{~mL}$ and $166 \mathrm{~mL}$ during the whole 19 days. So it was concluded that MU and TU were the appropriate digestion temperature for anaerobic co-digestion of dairy manure and edible mushroom cultivation waste. Compared to first period biogas yields of $\mathrm{MU}$ and TU during second period were $199 \mathrm{~mL} \cdot \mathrm{g}^{-1} \mathrm{VS}$ and $222 \mathrm{~mL} \cdot \mathrm{g}^{-1} \mathrm{VS}$ respectively, which were higher than that of first period.
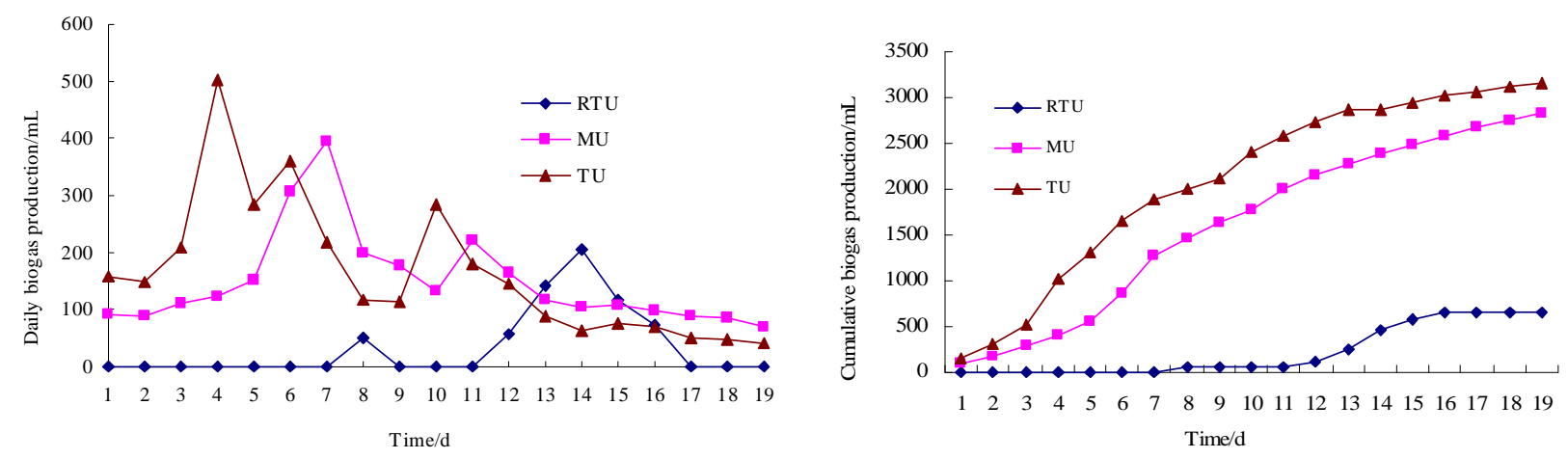

Fig.3 Variations of daily and cumulative biogas yield during second feed period 


\section{Conclusion}

Anaerobic co-digestion of dairy manure and edible mushroom cultivation waste was conducted to produce biogas using batch reactor under three temperature conditions of room temperature condition $\left(16.5^{\circ} \mathrm{C}-25^{\circ} \mathrm{C}\right)$, mesophilic condition $\left(36^{\circ} \mathrm{C}\right)$ and thermophilic condition $\left(55^{\circ} \mathrm{C}\right)$ with acclimated thickening sludge as inoculation sludge. Room temperature was unfit for anaerobic digestion with few biogas production. Mesophilic condition $\left(36^{\circ} \mathrm{C}\right)$ and thermophilic condition $\left(55^{\circ} \mathrm{C}\right)$ were appropriate digestion temperature under this experiment condition. Anaerobic digestion under thermophilic condition and mesophilic condition proceeded well, and the latter had earlier and higher daily biogas production peak. Compared to first feed period, second feed period achieved earlier biogas production peak and higher biogas yields of $199 \mathrm{~mL} \cdot \mathrm{g}^{-1} \mathrm{VS}$ and $222 \mathrm{~mL} \cdot \mathrm{g}^{-1} \mathrm{VS}$ respectively under mesophilic condition and thermophilic condition without lag phase. Seven to ten days of lag phase existed and biogas yields of MU and TU were $190 \mathrm{~mL} \cdot \mathrm{g}^{-1} \mathrm{VS}$ and $213 \mathrm{~mL} \cdot \mathrm{g}^{-1} \mathrm{VS}$ respectively during first feed period.

\section{Acknowledgements}

This work was financially supported by the fund of key program for scientific and technological support of Tianjin City (13ZCZDNC 09700).

\section{References}

[1]I. Angelidaki, L. Ellegaard and B. K. Ahring: Biotechnology and Bioenigeering, Vol. 42 (2) (1993), p.159

[2] J. Clemens, M. Trimborn and P. Weiland: Agriculture, Ecosystems and Environment, Vol. 112 (2006), p. 171

[3] X. Li, L. Zhao and J. Han: Chinese Biogas, Vol. 24 (4) (2006), p.23. (In Chinese)

[4] O. Guo, Y. Li and J Bai: Journal of Northwest Agriculture and Forestry University (Natural Science Edition), Vol. 37 (6) (2009), p.137. (In Chinese)

[5] P. Kaparaju, S. Luostarinen and E. Kalmari: Water Science and Technology, Vol. 45 (2002), p. 275

[6] X. Zhang: Anaerobic biological treatment of wastewater (China Environmental Science Industry Press, Beijing 1998).

[7] Yanling He: Wastewater Anaerobic Biological Treatment (Chinese Light Industry Press, Beijing 1998).

[8] Shidan Bao: Agricultural Soil Analysis (China Agricultural University Press, Beijing 2005).

[9] P. Weiland: Applied Biochemistry and Biotechnology 1, Vol. 109 (2003), p. 263 